\title{
Pancasila Value Education Through Learning The Role Playing Method of Elementary School Students (Case Study in Grade V SDN 1 Datar)
}

\author{
Arya Adittia \\ \{aryayaya2@gmail.com\} \\ Master of Basic Education Study Program, Faculty of Teacher Training and Education, \\ Universitas Muria Kudus
}

\begin{abstract}
This research is motivated by the problem of decreasing the number of supporters of Pancasila in Indonesian society which needs to be addressed immediately in the world of education, especially primary schools, so there needs to be a study of appropriate learning methods used by teachers in the context of Pancasila value education. This study aims to provide a description of the planning, implementation, and impact of Pancasila value education through role playing learning in elementary school students. Researchers used a qualitative research case study model in grade 5 SDN 1 Datar. Data analysis techniques in this study used the method of Miles and Huberman. The validity of the data uses a test of credibility, transfermability; Dependability; and confirmability. The results showed the teacher had a well planned and always read the literature before learning, the learning process was fun by facilitating students to develop their artistic potential, the impact was students becoming happy, not bored and easy to remember lessons, then the potential of students was facilitated and could practice their speaking skills and develop their sense confidence.
\end{abstract}

Keywords: Pancasila Value, Role Playing

\section{INTRODUCTION}

Pancasila is an ideology chosen by the Indonesian people which was formulated by the founders of the Nation which was born from the cultures that exist within Indonesia and has important functions and positions in the Indonesian state. The position of the Pancasila as the ideology of the Indonesian era is now threatened. The decline in the number can be said to be the need for education in the value of Pancasila.

Sumantri (in Sumantri and Sofyan, 2006: 5) explains that values are things contained in human conscience which provide more basis and moral principles which are the standard of beauty and efficiency or integrity of conscience (potential). Investment in society in Indonesia is carried out through education. Education in Indonesia has several phases, namely primary, junior and senior secondary education, and higher education. In the phase of basic education which in this case is the age of elementary school between 6-12 years, so at that age needs to be strengthened about the character values especially the Pancasila character.

The Ministry of Education and Culture has organized the 2013 curriculum in all sheltered educational institutions, including elementary schools. In the 2013 curriculum there is a new term that is strengthening character education (PPK). Pancasila value education is an inseparable part of national character education for children. The implementation of KDP in the education unit is carried out by the teacher. 
The teacher as a learning director does not only convey what the contents of the book or other references hold. however, teachers must also be able to plan learning well from the methods used, learning models, classroom management, approaches used, to learning media and teaching aids that will help the course of learning with the aim of making children happy, active or in other words the class becomes life.

One learning method that teachers can use to make learning fun is the role playing learning method. Based on the background that has been explained, the researchers conducted research on the value of Pancasila education in elementary school students in learning that can be done using the role playing learning method with case studies in 5th grade students of SDN 1 Datar with results in the form of descriptions .

\section{LITERATURE REVIEW}

\subsection{Pancasila Value Education}

Value or value (English) comes from the Latin valare or in ancient French volair which means price. Sumantri (1993: 3) states that Values are those contained in human conscience that provide more basis and moral principles which are the standard of beauty and efficiency or integrity of conscience (potential).

Mardiatmadja (in Sumantri and Sofyan, 2006: 61) explains that value education is an aid to students to realize and experience values and place them integrally in their whole lives. The values contained in Pancasila are explained through the items contained in the Decree of the Republic of Indonesia Republic of Indonesia Number I / MPR / 2003, which are the Almighty God, Humanity that is just and civilized, Indonesian Unity, and Society led by wisdom of wisdom in representative deliberation and Social Justice for all Indonesian people.

\subsection{Role Playing Learning Methods (Role Playing)}

In teaching and learning activities in the classroom a teacher is a director. As a director, teachers must have creativity in determining the flow of learning to be active with a pleasant atmosphere so that students can learn comfortably, one way is to use appropriate learning methods. Fathurrohamn and Sobry (2010: 15) state that in a learning method it is necessary to use appropriate learning methods to achieve the stated learning objectives.

Material related to social issues such as the education of Pancasila values, is difficult to explain using only the lecture method, so there is a need for methods that can dramatize an event by making students play a role in it. Wina Sanjaya (2010: 161) gives the sense that "The role playing method is a method of learning as part of a form of simulation that is directed to create historical events, create actual events, or events that arise in the future".

\subsection{Purpose of Application of the Role Playing Method}

The purpose of applying the role playing learning method is as follows:

(1) Exploring the talents of students by giving space for students to channel their talents and interests in acting;

(2) Provide student motivation to deepen learning material;

(3) Developing the ability to communicate as a provision for community life.

\subsection{Steps of the Role Playing Method}

Roestiyah (2008: 91) mentions the steps in applying the role playing method, i.e.

1) The teacher must explain to students to introduce this technique. 
2) The teacher must choose an urgent problem, so that it attracts students.

3) In order for students to understand the event, the teacher must be able to tell while arranging the first scene.

4) If there is a voluntary willingness from students to play a role, please, please respond to it but the teacher must consider whether the student is right to perform the role

5) Explain to the actors as well as possible, so that they know the role of the role, mastering the problem of panda mimic or dialogue.

6) Students who do not participate must be active spectators, in addition to listening and seeing, they must be able to give advice and criticism after the cast is finished.

7) If students are not accustomed, the teacher needs to help in raising the first sentence in the dialogue.

8) After the play is in a climax situation, it must be stopped, so that the possibilities of solving the problem can be discussed in general.

9) As a follow-up to the results of the discussion, although the problem may not be solved, it is necessary to open a question and answer session, discussion or make a statement in the form of a play.

\section{RESEARCH METHOD}

\subsection{Research design}

This research uses qualitative research. Bogdan and Taylor (in Moleong, 2012: 4) state that "Qualitative research is a research procedure that produces descriptive data in the form of written or oral words from people and observed behavior. The data generated comes from interview scripts, field notes, photographs and other official documents. With qualitative research, this case study model will provide an overview or description of Pancasila value education through the role playing learning method for elementary school students in grade 5 public elementary school 1 Datar Mayong District, Jepara Regency.

\subsection{Data and Data Sources}

According to the data source, the grouping of data in this study is divided into two, namely:

\section{Primary data}

In this study primary data were obtained from interviews and observations made by researchers when they entered the research field. The researcher selects informants directly related to the research and is also able to provide accurate information related to the research focus. Primary data were obtained from verbal words and behaviors that can be observed from grade 5 teachers and grade 5 students and principals in SD Negeri 1 Datar.

\section{Secondary Data}

In this study, secondary data needed is as follows:

a. Student score sheet or evaluation results of elementary school student activities in SD

Negeri 1 Datar on Pancasila value education activities through the role playing learning method.

b. Documentation of Pancasila value education activities through role playing learning methods for elementary school students in SD Negeri 1 Datar. 


\subsection{Data collection}

In this study using data collection techniques as follows:

\section{Observation}

Observation is a technique or a way to collect data by observing current activities. In this study observations were made during the study to obtain the data needed in depth about Pancasila value education through learning the role playing methods of elementary school students.

\section{Interview}

Interview or commonly referred to as an interview form of data collection techniques conducted verbally in face-to-face meetings with individuals or groups conducted individually. (Sukmadinata, 2010: 216). In this study interviews were conducted related to the education of Pancasila values through learning the role playing methods of elementary school students conducted in SD Negeri 1 Datar especially grade 5 with related people namely teachers and students at SD Negeri 1 Datar. As supporting material, interviews were also conducted with school principals and Pancasila activists.

\section{Documentation}

Documentation is a data collection technique by collecting and analyzing documents, whether written, image or electronic (Sukmadinata, 2010: 221). In the documentation, the data needed in this study are:

a. 2013 curriculum book used by students.

b. Notebook / worksheet used by students in Pancasila value education activities through the role play method.

c. Photos related to implementation, media, strategy, and facilities and infrastructure used in the Pancasila value education process through learning the role playing method.

d. A list of student values to support the evaluation of Pancasila value education activities and show changes in students from the Pancasila value education process through learning the role playing method.

\subsection{Data analysis}

In this study, the data analysis technique used by researchers is the Miles and Huberman model. Data analysis in qualitative research, carried out at the time of data collection takes place, and after the completion of data collection within a certain period. Data components according to miles and huberman can be illustrated as follows: 


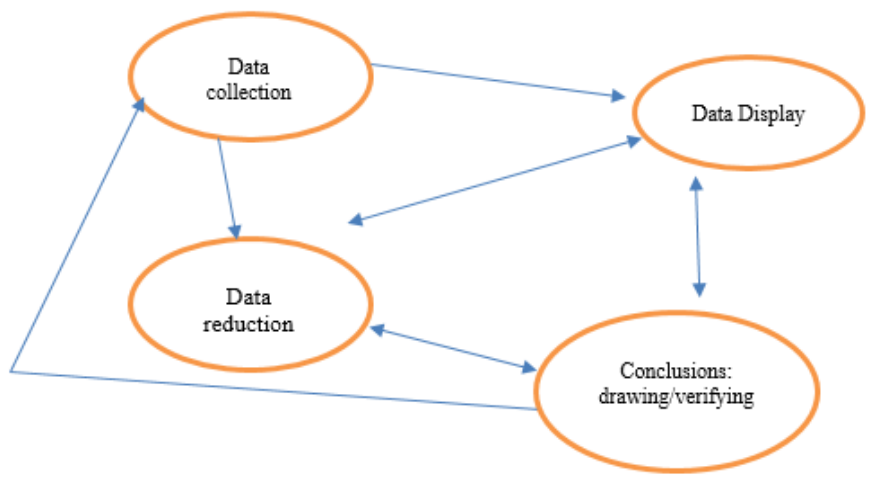

Figure 1. Miles and Huberman data analysis techniques

\subsection{Data Validity}

According to Sugiyono (2015: 365), in qualitative research, findings or data can be declared valid if there are no reported differences with what actually happened to the object under study. In this study using data analysis in the form of credibility, transferability, dependability, and confirmability. As stated by Sugiyono (2015:366), that there are 4 testing methods that can be taken so that research can be accounted for, including credibility (internal validity / truth), transferability (external validity / application / generalization), dependability (reliability / consistency), and confirmability (objectivity / neutrality).

\section{RESEARCH RESULTS AND DISCUSSION}

\subsection{RESULTS}

In this chapter the description, analysis and discussion of research results are presented. The description aims to provide information about the planning of Pancasila values education, the informant's description of the education of Pancasila values by the role playing method and the impact of the existence of Pancasila values education by the role playing method

\subsection{DISCUSSION}

\section{a. Pancasila Value Education Planning}

Learning planning is the process of preparing learning material, using media, using approaches, using methods, and evaluating in an allocation of time to be carried out at a certain time to achieve a goal (Majid, 2009: 17). Educational learning planning for the value of Pancasila on the results of this study is carried out as in general, namely determining the material, the use of media, the approaches and methods used and their assessments.

\section{b. The Education Process of Pancasila Values Using the Role Playing Method}

1. Pancasila value education habituation activities

Pancasila value education activities in this study were carried out by habituating the attitude of Pancasila values for students since the beginning of learning so that students are 
accustomed to doing so in social life. The activities carried out in this research are the culture of queuing to shake hands, pray, sing Indonesia Raya songs, always be invited to consult and be fair in every activity and then cultivate literacy.

\section{Approach Techniques and Learning Media}

The learning approach technique applied by the teacher when in class is a group approach. This means that the given structured tasks are done in groups. In this study the teacher still uses conventional learning media.

\section{Learning the Value of Pancasila with Role Playing}

The role playing method is one of the effective learning methods in learning the value of Pancasila. Through this method students experience an increase in motivation as seen from the activeness of students when learning the value of Pancasila takes place. This supports Saputra's research (2015) which shows the results that the application of the role playing method in social studies subject matter in the economic activities of the community in SD Negeri 2 Kecemen can foster student motivation so that student learning outcomes increase. In its application in this study students are invited to play the role in which the script and story line are made with the group with the theme of the value of unity and unity.

\section{c. The Impact of Pancasila Value Education Through Learning the Role Playing Method}

Broadly speaking, the impact of Pancasila values education through the learning of role playing methods is that role playing learning can practice speaking skills and train students' self-confidence in learning interactions. Another impact that can be seen is the value of Pancasila education which is one of the social sciences is one way to build good character in students. This supports the research of Wahyudi et al (2014) which says the use of role playing methods in social studies learning is one of the ways that teachers can use to improve student character values.

\section{CONCLUSIONS AND SUGGESTIONS}

\subsection{CONCLUSION}

In this study several conclusions were drawn about the education of the value of Pancasila through learning the role playing method in SD Negeri 1 Datar as follows:

1. Careful planning of learning and enriching knowledge through literacy is important so that education related to social sciences such as Pancasila values education can be well absorbed by students.

2. Pancasila value education can be done every day through habituation of Pancasila attitudes in learning and outside learning.

3. Pancasila value education using the role playing method makes students active, the atmosphere becomes fun, students easily remember the material, can facilitate students' potential, trains students to explore relationships between people which is one of HOTS (High order thinking skill) learning, and can practice speaking skills and increase selfconfidence. 


\subsection{SUGGESTION}

Based on the results of the study, suggestions that can be put forward are as follows:

1. Teachers can use role playing learning methods with scripts and storylines designed by students themselves in delivering social science materials such as Pancasila value education.

2. Other research can continue this research with a broader scope, not limited to one aspect.

3. As input to school policies in general and Jepara District Public Elementary 1 Flat School in particular to keep increasing the application of Pancasila values education in the learning process or other activities in order to create a generation that can practice, secure and perpetuate Pancasila in various lines of life.

\section{REFERENCE}

Azizan, Nashran. 2017. Educational value of Pancasila in students in elementary schools. Proceedings of the Annual National Seminar of the Faculty of Social Sciences, Medan State University. Vol. 1 (1) Pg. 292-294.

Hasan, Iqbal. 2002. Main Material Research Methodology and Its Applications. Jakarta: Ghalia Indonesia

Hayati, Safita Sri. 2017. Role Playing Method in Nationality-Based Character Education Efforts. Proceedings of the Annual National Seminar of the Faculty of Social Sciences, Medan State University. Vol. 1 (1) Pg. 245-248.

Herdiansyah, Haris. 2010. Qualitative Research Methods for the Social Sciences. Jakarta: Salemba Humanika.

Katsoff, Louis (over Soejono Soemargono). 2004. Introduction to Philosophy. Yogyakarta: Tiara Wacana

Kaelan 2004. Pancasila Education. Yogyakarta: Offset Paradigm.

Republic of Indonesia MPR Decree No. I Th 2003. (https://id.wikipedia.org/wiki/Pancasila accessed on 2 January 2019)

Lamajau, Eresia. 2017. Improving the Speaking Skills of Class V Students of SDN Sampaka Kec. Bualemo Kab. Be Proud Through Group Discussion Methods. Online Creative Journal, Vol. 5 No. 1

Majid, Abdul. 2009. Learning Planning. Bandung: Teen Rosdakarya

Makmun, Abin Syamsudin. 2015. Educational psychology. Bandung: Teen rosdakarya.

Mulyasa 2004. Implementation of the 2004 Curriculum: CBC Learning Guidelines. Bandung: Teen Rosdakarya.

Moleong, Lexy. 2012. Qualitative Research Methodology. Bandung: Youth Rosda Karya.

Government Regulation No. 19 th 2015 concerning National Education Standards. (https://www.hukumonline.com/pusatdata/detail/21141/nprt/707/pp-no-19-tahun-2005standard-national-education accessed on 2 January 2019).

Government Regulation No. 87 Th. 2017 on Character Strengthening Education. (2017). http://setkab.go.id/wp-content/uploads/2017/09/Perpres_Nomor_87_Tahun_2017.pdf accessed on 2 January 2019).

Pidarta, Made. 2007. Educational foundation. Jakarta: Rineka Cipta

Roestiyah. 2008. Teaching and Learning Strategies. Jakarta: Rineka Cipta.

Sanjaya, Vienna. 2010. Learning Strategy Oriented Education Process Standards. Jakarta: Prenada Media Group. 
Saputra, Dedi Riskia. 2015. Thesis. The Application of Role Playing Method to Improve Ips Learning Outcomes in Class V Sd Negeri 2 Kecemen, Manisrenggo, Klaten. Faculty of Education Yogyakarta State University

Setiawan, Deny. 2017. Citizenship Education. Medan: Larispa Indonesia.

Setiawan, Sakina Rakhma Diah. 17 July 2018. Survey: In 13 Years, Pro Pancasila Public Percentage Continues to Decrease. (https://nasional.kompas.com/read/2018/07/17/15580981/surve-in13-year- percentage-publicpro-pancasila-terus-decreased on January 2, 2019)

Soegeng, A.Y. 2016. Research Basics. Yogyakarta: Magnum Pustaka Utama.

Sugiyono 2015. Business Research Methods (Quantitative, Qualitative Approach, R\&D). Bandung: Alfabeta.

Sukmadinata, Nana Syaodih.2010. Educational research methods. Bandung: Teen Rosdakarya

Sumantri, Endang. 2003. Resume of Philosophy of Value. Bandung: Postgraduate UPI.

Sumantri, Endnag and Sofyan Sauri. 2006. Basic Concepts of Value Education. Bandung: Native Mekar

Supriadi., Hadi Mulyono., Sularmi. Efforts to Increase Understanding of the Concepts of the Meanings of the Sila Pancasila Symbols through the Role Playing Model for Elementary School Students. Dididaka Dwija Indria.

Triyono and Nur Fandilah. 2018. Educational value of Pancasila in primary schools. Civics Journal: Citizenship Study Media. Vol. 15 (2) Pg. 161 - 169.

Republic of Indonesia Law No. 20 th. 2003 on the National Education System. (Http://sipuu.setkab.go.id/PUUdoc/7308/UU0202003.htm accessed on 2 January 2019)

Wahyudi, Achmad Basari Eko and Siti Partini Suardiman. 2014. Improving Social Character Learning Outcomes and Using the Role Playing Method in Elementary Students. Prima Edukasia Vol 1: No 2 